\title{
Human endodermal sinus tumour in nude mice and its markers for diagnosis and management
}

\author{
T. TAKEUCHI ${ }^{1}$, M. NAKAYASU ${ }^{1}$, S. HIROHASHI ${ }^{2}$, T. KAMEYA ${ }^{2}, \mathrm{M}$. KANEKO ${ }^{3}$, \\ K. YOKOMORI ${ }^{3}$, AND Y. TSUCHIDA ${ }^{3}$
}

From the ${ }^{1}$ Biochemistry Division and ${ }^{2}$ Pathology Division, National Cancer Center Research Institute, Tsukiji, Chuo-ku, Tokyo 104, and ${ }^{3}$ Department of Paediatric Surgery, Faculty of Medicine, University of Tokyo, Hongo, Bunkyo-ku, Tokyo 113, Japan

SUMMARY Two human endodermal sinus tumours (yolk sac tumours) were transplanted successfully into nude mice. The transplanted tumours maintained not only morphological characters, such as Schiller-Duval bodies, but also the ability to synthesise alpha-fetoprotein, lactic dehydrogenase 1 , liver and bone type alkaline phosphatase, and some human serum proteins. Since these tumours produced lactic dehydrogenase 1 but not the other four isozymes of lactic dehydrogenase, this isozyme, like alpha-fetoprotein, seems to be a good marker for the diagnosis and management of cases of endodermal sinus tumour. One of the two tumours produced another fetal antigen or carcinoembryonic antigen in addition to alpha-fetoprotein. These two endodermal sinus tumours, with their various markers in nude mice, will be useful in studies on diagnostic markers.

The term 'endodermal sinus tumour' was first proposed by Teilum (1959) on the basis of the histological resemblance of these tumours to the endodermal sinuses of the yolk sac in rodents. The most specific biochemical character is alphafetoprotein (AFP), which is a useful marker in the diagnosis and management of cases of this tumour (Teilum et al., 1974, 1975; Tsuchida et al., 1975).

We have successfully transplanted two endodermal sinus tumours into nude mice. These transplanted tumours not only maintained the morphological characters of the original tumours but also continued to synthesise several biochemical substances which might possibly be used as diagnostic markers.

\section{Material and methods}

\section{TUMOURS}

Tumours were removed from patient 1 , a 4-year-old girl with a sacrococcygeal tumour, and patient 2 , a 2-year-old boy with a testicular tumour, in the Department of Paediatric Surgery, Tokyo University Hospital.

\section{ANIMALS}

Male nude mice, 4 to 8 weeks old, with the genetic character of BALB/c were used. They were bred and

Received for publication 8 November 1978 maintained in air-filtering cages under an air ventilator.

\section{MICROSCOPY}

For light microscopy tissues were fixed in formalin, and sections were stained with haematoxylin and eosin. For immunohistochemical studies on the position of AFP, tissues were fixed in $95 \%$ ethanol containing $1 \%$ acetic acid for 24 to 36 hours and embedded in paraffin at below $60^{\circ} \mathrm{C} ; 4 \mu \mathrm{m}$ thick sections were deparaffinised. Indirect immunofluorescent staining of the sections was performed using rabbit antiserum to human AFP (Miles Lab, Ill, USA) and fluorescein isothiocyanate (FITC)labelled goat antiserum to rabbit gammaglobulin (Miles Lab). The specificity of rabbit antiserum to human AFP was assayed by immunoelectrophoresis and double diffusion against human AFP (Calbiochem, Calif., USA) and against goat antiserum to rabbit gammaglobulin.

Alkaline phosphatase was examined histochemically, as described by Kameya et al. (1973).

\section{ASSAYS}

Homogenates of tissues were prepared in a Polytron homogeniser (Kinematica $\mathrm{GmbH}$, Lucerne, Switzerland) in 4 volumes of $10 \mathrm{~mm}$ Tris- $\mathrm{HCl}$ (pH 7.4) containing $0.15 \mathrm{M} \mathrm{NaCl}$. The homogenates were centrifuged at $28000 \mathrm{~g}$ for 20 minutes, and the supernatants were used for double antibody radio- 
immunoassays of AFP, carcinoembryonic antigen (CEA), and human chorionic gonadotropin (HCG), and for enzyme assays of lactic dehydrogenase (LDH) and alkaline phosphatase.

AFP, CEA, and HCG were assayed with the radioimmunoassay kit of Dainabot Radioisotope Institute (Tokyo). The assays for AFP, CEA, and HCG, respectively, had sensitivities of $5 \mathrm{ng}, 1 \mathrm{ng}$, and $1 \mathrm{ng}$ per $\mathrm{ml}$, and concentrations of over $20 \mathrm{ng}$, $2.5 \mathrm{ng}$, and $2 \mathrm{ng}$ per $\mathrm{ml}$ were considered abnormal.

LDH activity for conversion of pyruvate to lactate was assayed by measuring remaining pyruvate with 2,4-dinitrophenylhydrazine. LDH activity was expressed as Cabaud-Wróblewski units (Cabaud and Wróblewski, 1958).

Alkaline phosphatase was assayed using $p$ nitrophenylphosphate as a substrate and expressed as Bessey-Lowry units (Bessey et al., 1946). Enzyme inhibition by L-phenylalanine and heat were measured as described by Fishman et al. (1976).

\section{ELECTROPHORESIS}

Electrophoresis of LDH was carried out on $1 \%$ agar gel plate for 1 hour at $5 \mathrm{~mA}$ per $\mathrm{cm}$ in $0.05 \mathrm{M}$ veronal buffer ( $\mathrm{pH} \mathrm{8.6)}$. The LDH isozymes separated were stained with $0.2 \mathrm{M}$ Tris- $\mathrm{HCl}$ buffer ( $\mathrm{pH} \mathrm{7.4)}$ containing $0.11 \mathrm{~m}$ sodium lactate, $0.06 \mathrm{M} \mathrm{KCN}, 1 \mathrm{~mm}$ NAD, $3.3 \mathrm{~mm}$ phenazine methosulphate, and 2.5 mM nitroblue tetrazolium.

Electrophoresis of alkaline phosphatase was carried out on $1 \%$ agar gel plates for 3 hours at $5 \mathrm{~mA}$ per $\mathrm{cm}$ in $0.2 \mathrm{M}$ Tris- $\mathrm{HCl}$ buffer (pH 8.8). The isozymes separated were stained with $p$-toluidinum 5-bromo3-indolyl phosphate.

Immunoelectrophoresis was carried out on $1.2 \%$ agar gel plates for 2 hours at $3 \mathrm{~mA}$ per $\mathrm{cm}$ in $0.05 \mathrm{M}$

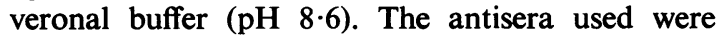
products of Miles Lab, Kankakee, Ill, USA.

\section{Results}

\section{GROWTH}

The transplanted endodermal sinus tumour (EST 1) of patient $1 \mathrm{grew}$ to 2 to $4 \mathrm{~cm}$ diameter with weights of 5 to $10 \mathrm{~g}$ in two months. EST 1 forms cysts containing brownish mucous fluid. The transplant tumour (EST 2) of patient 2 grew to 0.5 to $1.0 \mathrm{~cm}$ diameter with weights of 0.4 to $2.0 \mathrm{~g}$ in two months. It is a solid tumour without cysts.

\section{HISTOLOGICAL FINDINGS}

Histologically the original tumours of patient 1 had a papillotubular appearance with partial glomeruloid structures called Schiller-Duval bodies (Fig. 1a). These histological features are characteristic of endodermal sinus tumour proposed by Teilum (1959). EST 1 had a similar papillotubular appearance but with slightly less abundant stroma (Fig. 1b). In electron micrographs of EST 1, accumulation of basement membrane-like substance was seen in the stroma adjacent to the tumour cells. A large, dense, membrane-bound body with a partial myelin-like lamellar structure was observed.

Histologically, the original tumour of patient 2 had a cystic papillary structure (Fig. $2 a$ ) showing the characteristic feature of endodermal sinus tumour (Teilum, 1959). EST 2 had a very similar appearance containing the glomeruloid structure compatible with Schiller-Duval bodies (Fig. 2b). In electron micrographs, little of the basement membrane-like
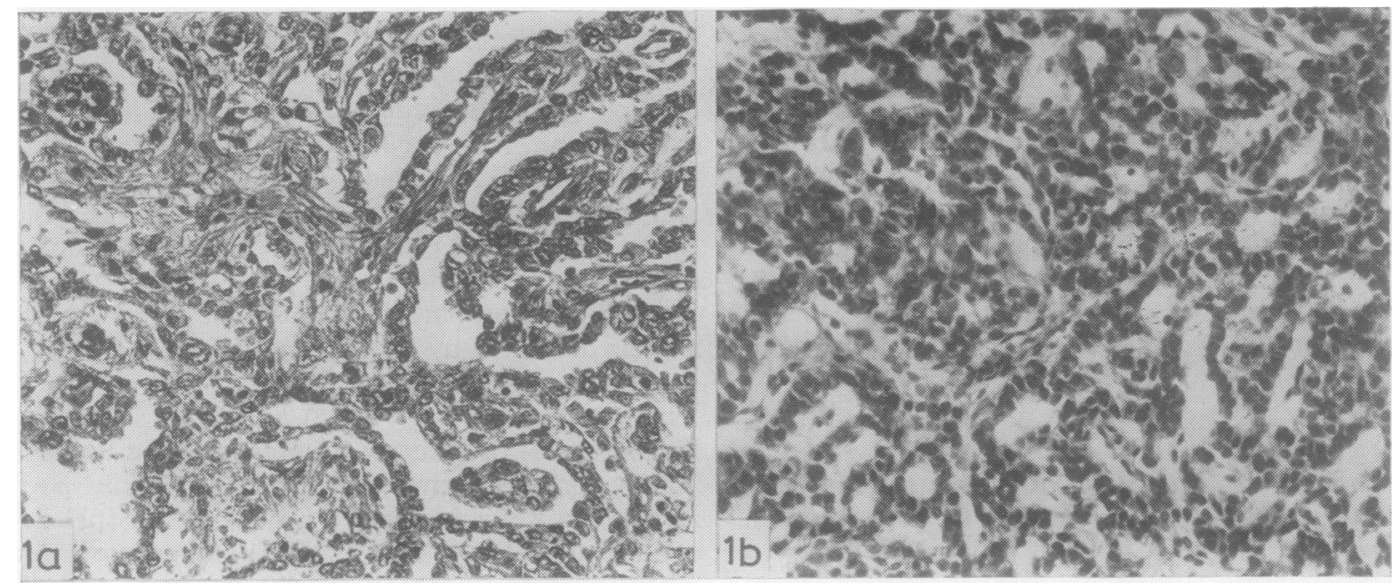

Fig. 1 (a) Endodermal sinus tumour of patient 1. (b) Endodermal sinus tumour transplanted into a nude mouse (EST 1). $(\times 175)$ 


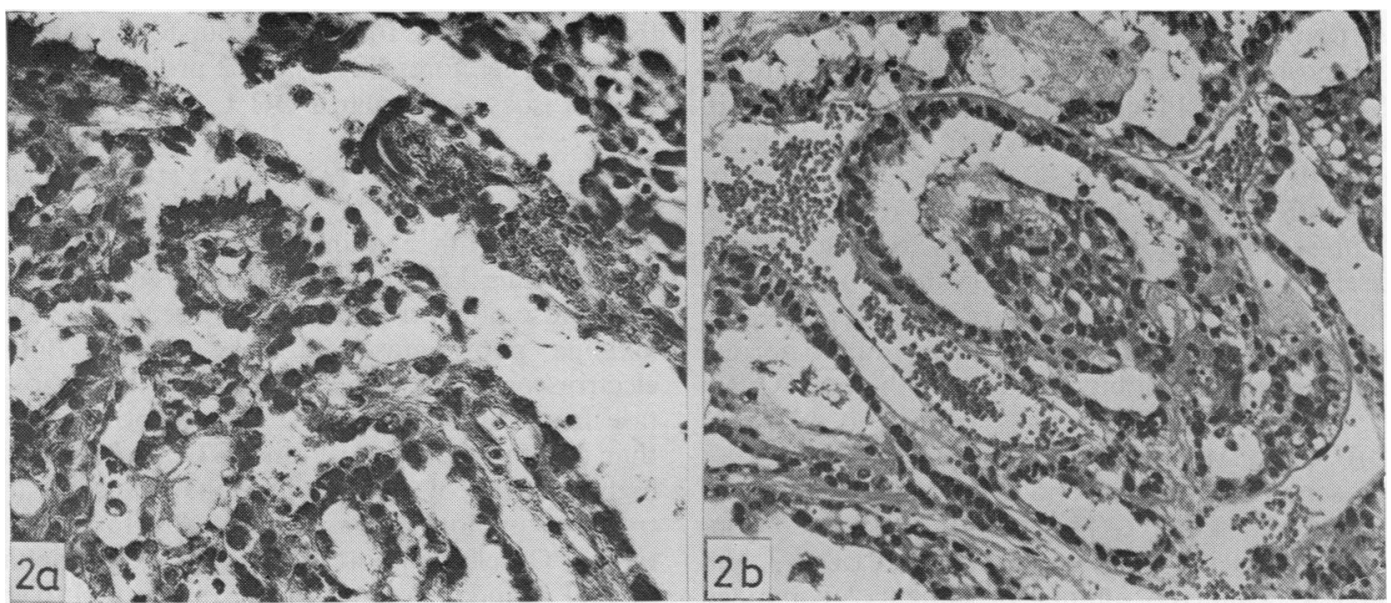

Fig. 2 (a) Endodermal sinus tumour of patient 2. (b) Endodermal sinus tumour transplanted into a nude mouse (EST 2). $(\times 175)$

substance was found. A sheet of epithelial cells connected by desmosomes with poorly developed rough endoplasmic membranes, occasional dense bodies in the cytoplasm, and lumina with a few microvilli were observed.

\section{BIOCHEMICAL FINDINGS}

The biochemical findings on the two tumours are shown in the Table. Results on EST 1 and 2 were similar to those on the tumours of patients 1 and 2 , respectively. The activities of LDH in EST 1 and 2 and in the serum of tumour-bearing mice were higher than those in patients 1 and 2 . The serum concentrations of AFP in tumour-bearing nude mice were similar to, or a little higher than, those in the two patients. But EST 1 and 2 contained concentrations of AFP 8-200 times higher than those in the original tumours of patients 1 and 2. A little CEA was detected in the tumour of patient 2 and in EST 2, but not in the tumour of patient 1 or in EST 1 .

Table Biochemical data

(a) Serum

\begin{tabular}{|c|c|c|c|c|c|c|}
\hline & \multicolumn{2}{|c|}{ Normal range } & \multirow[t]{2}{*}{ Patient 1} & \multirow{2}{*}{$\begin{array}{l}\text { Nude mice with } \\
\text { EST } 1\end{array}$} & \multirow[t]{2}{*}{ Patient 2} & \multirow{2}{*}{$\begin{array}{l}\text { Nude mice with } \\
\text { EST } 2\end{array}$} \\
\hline & Human & Nude mice & & & & \\
\hline $\begin{array}{l}\text { Lactic dehydrogenase } \\
\text { (Cabaud-Wróblewski) }\end{array}$ & $200-500$ & $1000-2000$ & $530-8100$ & 4680 & $400-3350$ & 3850 \\
\hline $\begin{array}{l}\text { Alkaline phosphatase } \\
\text { (Bessey-Lowry) }\end{array}$ & $2 \cdot 8-6 \cdot 7$ & $0 \cdot 8-2 \cdot 0$ & $2 \cdot 3-3 \cdot 7$ & $1 \cdot 1-2 \cdot 6$ & $4 \cdot 4-6 \cdot 9$ & $3 \cdot 5-7 \cdot 2$ \\
\hline $\begin{array}{l}\text { Alpha-fetoprotein }(\mathrm{ng} / \mathrm{ml}) \\
\text { Carcinoembryonic antigen } \\
(\mathrm{ng} / \mathrm{ml})\end{array}$ & $\begin{array}{l}<20 \\
<2 \cdot 5\end{array}$ & $\begin{array}{l}<20 \\
<2 \cdot 5\end{array}$ & $\begin{array}{l}6400 \\
\text { nd }\end{array}$ & $\begin{array}{l}1060-6500 \\
<1 \cdot 0\end{array}$ & $\begin{array}{l}900-952 \\
<1.0\end{array}$ & $\begin{array}{l}1460-3200 \\
<1.0\end{array}$ \\
\hline $\begin{array}{l}\text { Human chorionic } \\
\text { gonadotropin }(\mathrm{ng} / \mathrm{ml})\end{array}$ & $<2 \cdot 0$ & $<2 \cdot 0$ & $<1.0$ & $<1.0$ & $<1.0$ & $<1.0$ \\
\hline
\end{tabular}

(b) Tumour

\begin{tabular}{|c|c|c|c|c|}
\hline & Patient I & Nude mice with EST 1 & Patient 2 & Nude mice with EST 2 \\
\hline $\begin{array}{l}\text { Lactic dehydrogenase } \\
\text { (Cabaud-Wróblewski) }\end{array}$ & 150000 & 420000 & 106000 & 473000 \\
\hline $\begin{array}{l}\text { Alkaline phosphatase } \\
\text { (Bessey-Lowry) }\end{array}$ & nd & 63.0 & $40 \cdot 0$ & $69 \cdot 8$ \\
\hline $\begin{array}{l}\text { Alpha-fetoprotein (ng/g) } \\
\text { Carcinoembryonic antigen (ng/g) } \\
\text { Human chorionic gonadotropin } \\
\text { (ng/g) }\end{array}$ & $\begin{array}{l}870 \\
\text { nd } \\
\text { nd }\end{array}$ & $\begin{array}{l}6800-8000 \\
<5 \cdot 0 \\
<5 \cdot 0\end{array}$ & $\begin{array}{l}210 \\
240 \\
\text { nd }\end{array}$ & $\begin{array}{l}6600-39000 \\
100-670 \\
<5 \cdot 0\end{array}$ \\
\hline
\end{tabular}

nd $=$ not determined. 
IMMUNOFLUORESCENT STAINING OF AFP

AFP-positive cells were scattered in clusters in the EST 1 tumour. Fluorescence was located mainly in the cytoplasm of tumour cells, with a little in intercellular spaces (Fig. 3a). In the EST 2, tumour localisation of AFP had a scattered reticular form. Fluorescence was located mainly in intercellular spaces with a little in the cytoplasm of tumour cells (Fig. 3b). In controls, no fluorescence was observed in the EST 1 and 2 tumours using rabbit normal serum instead of rabbit antiserum to human AFP.

\section{LDH ISOZYME}

The sera of patients 1 and 2 contained predominantly human LDH 1 . The tumour in patient 1 contained high activities of human LDH 1, LDH 3, and LDH 4, while the tumour of patient 2 contained mainly human LDH 1. The sera of control nude mice contained mainly mouse LDH 5, with small amounts of mouse LDH 1, LDH 2, LDH 3, and LDH 4. EST 1 and 2, and the sera of mice with these tumours, contained high activities of human LDH 1 and mouse LDH 5, with low activities of mouse LDH 2, LDH 3, and LDH 4 (Fig. 4). Human LDH 1 overlapped mouse LDH 1, which was present at low concentration in the sera of control nude mice. Since mouse LDH was located between human LDH 3 and LDH 4 in the gel, it served as a very good calibration marker for comparison with human LDH isozymes. The increase in LDH activity in EST 1 and 2, and in the sera of mice with these tumours, was found to be due to that of human LDH 1. Therefore, EST 1 and 2 produced only one type of isozyme, human LDH 1.

\section{ALKALINE PHOSPHATASE ISOZYME AND ITS CHARACTER}

Since the serum alkaline phosphatase activities of mice bearing EST 2 were about three times higher than those of control mice, EST 2 seemed to secrete alkaline phosphatase into the serum. But the electrophoretic pattern of serum alkaline phosphatase from mice with EST 2 showed no band other than that in the control serum. EST 1 and 2 contained high activities of alkaline phosphatase, comparable to those in normal mouse liver (50 to 75 units/g tissue). On electrophoresis the alkaline phosphatase of EST 1 and 2 became widely distributed over the region from the position of human liver type to that of human placental type isozyme. The enzyme activities in EST 1 and 2 were reduced to $7 \%$ and $12 \%$ of the original value by heat treatment $\left(65^{\circ} \mathrm{C}\right.$, $10 \mathrm{~min}$ ) but were inhibited only to $92 \%$ and $95 \%$ of the original value by $5 \mathrm{~mm}$ L-phenylalanine. These characters are similar to those of liver and bone type alkaline phosphatase (Fishman and Singer, 1976). Histochemical studies using azo dye showed that the alkaline phosphatase was located in membranes of the tumour cells and in those of endothelial cells of EST 1 and 2 (Fig. 5). After heat treatment $\left(65^{\circ} \mathrm{C}, 5 \mathrm{~min}\right)$ no alkaline phosphatase could be detected by staining.
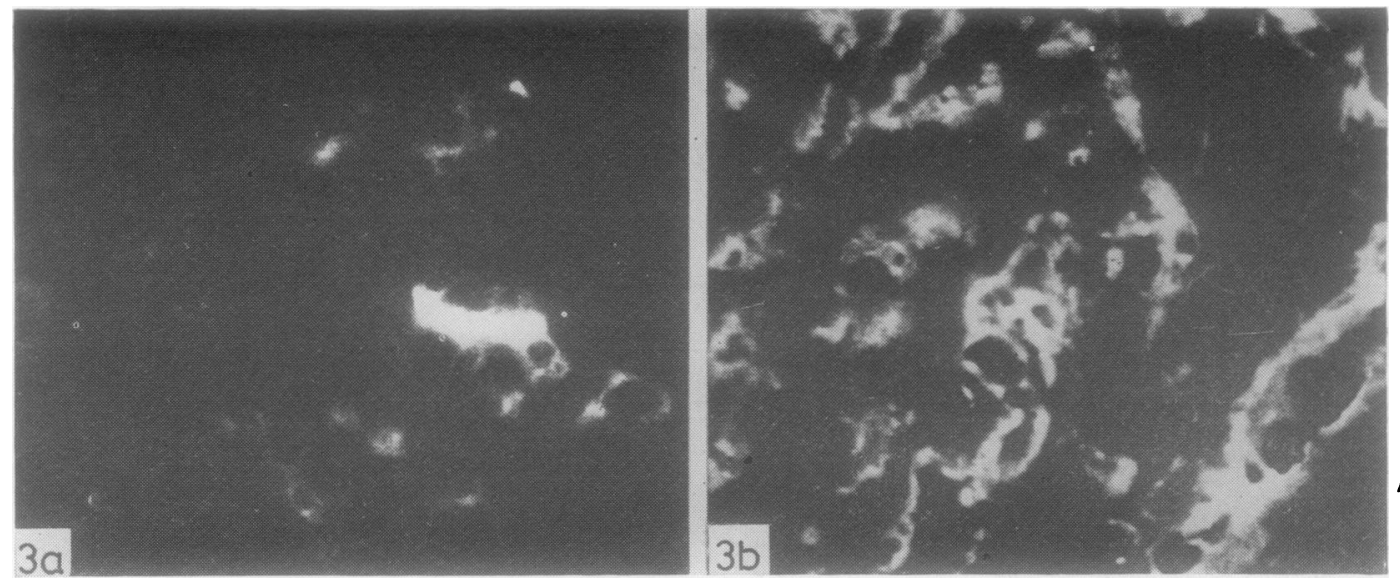

Fig. 3 (a) Localisation of AFP-positive cells in clusters shown with FITC-labelled antibody in EST 1. $(\times 136)$ (b) Reticular-form distribution of AFP shown with FITC-labelled antibody in EST 2. (×136) 


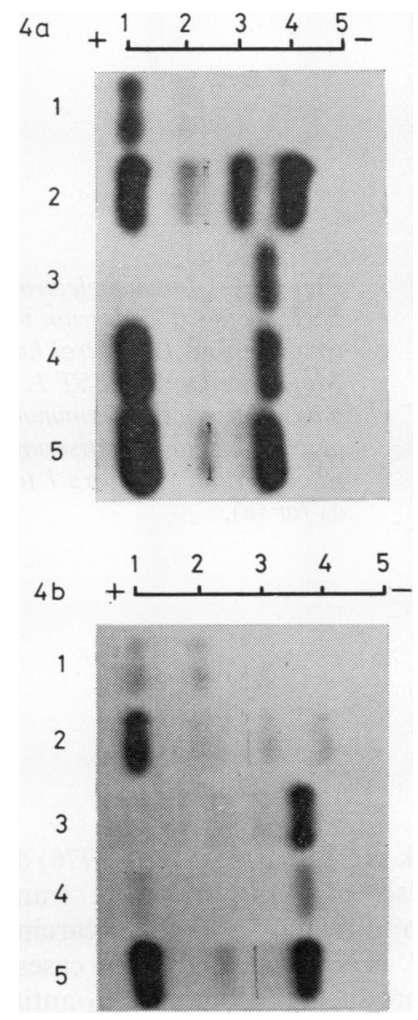

Fig. 4 (a) LDH isozyme pattern of EST 1. 1, Serum of patient 1. 2, Tumour homogenate of patient 1. 3, Serum of control mouse. 4, Serum of mouse with EST 1. 5, Homogenate of EST 1. Numbers at the top indicate the positions of human $\mathrm{LDH}$ isozymes from heart type [1] to muscle type [5]. (b) $\mathrm{LDH}$ isozyme pattern of EST 2. Numbers are as for (a).
IMMUNOELECTROPHORESIS

Control mouse serum showed no remarkable immunoprecipitation line when treated with rabbit antiserum to whole human serum. The sera of mice with EST 1 and EST 2 gave immunoprecipitation lines in the regions of alpha-1-antitrypsin and albumin, respectively, when treated with rabbit antiserum to whole human serum (Fig. 6); these lines were found to be due to alpha-1-antitrypsin and albumin using rabbit antisera to human alpha1-antitrypsin and human albumin, respectively.

\section{Discussion}

The endodermal sinus tumours transplanted into nude mice in this study (EST 1 and 2) maintained papillary structures similar to those of the original tumours. Shimosato et al. (1976) have reported that the original morphological characteristics of tumours are usually maintained well in nude mice. Teilum et al. (1974) and Tsuchida et al. (1975) reported that the AFP in the tumour cells was located in the characteristic endodermal sinuses and in PASpositive hyaline globules. We found that in EST 1 AFP was present mainly in the cytoplasm in clusters of tumour cells, while in EST 2 it had an irregular reticular arrangement in the interstitium.

The functions of the original tumours were also well maintained in nude mice, namely, both tumours produced AFP, which is a characteristic of endodermal sinus tumour (Teilum et al., 1974, 1975; Tsuchida et al., 1975), and also produced LDH, alkaline phosphatase, and human serum proteins. Actually, AFP is often used in the diagnosis of these tumours and in the postoperative management of

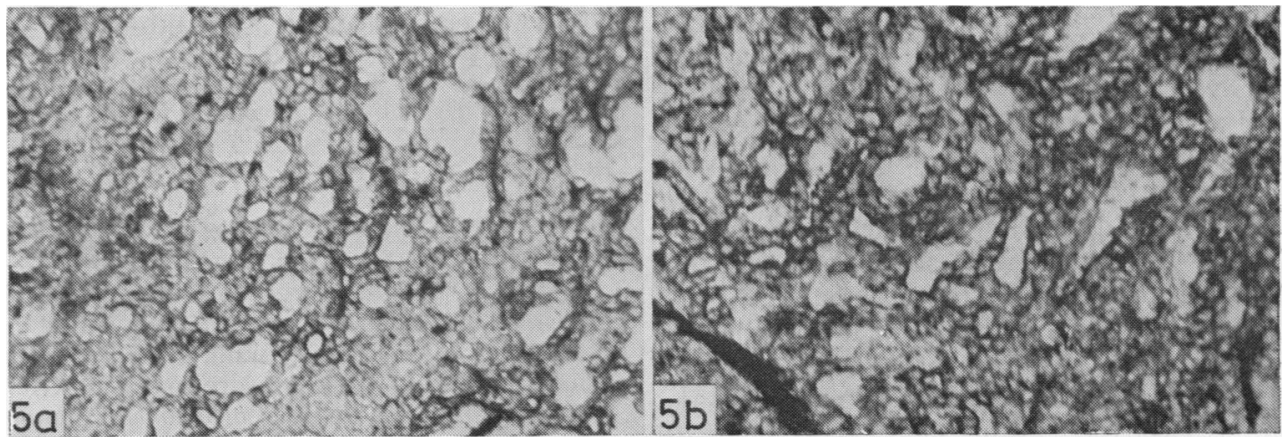

Fig. 5 Localisation of alkaline phosphatase in tumour tissues; alkaline phosphatase is located around cell membranes. (a) EST 1. (b) EST 2. (×136) 


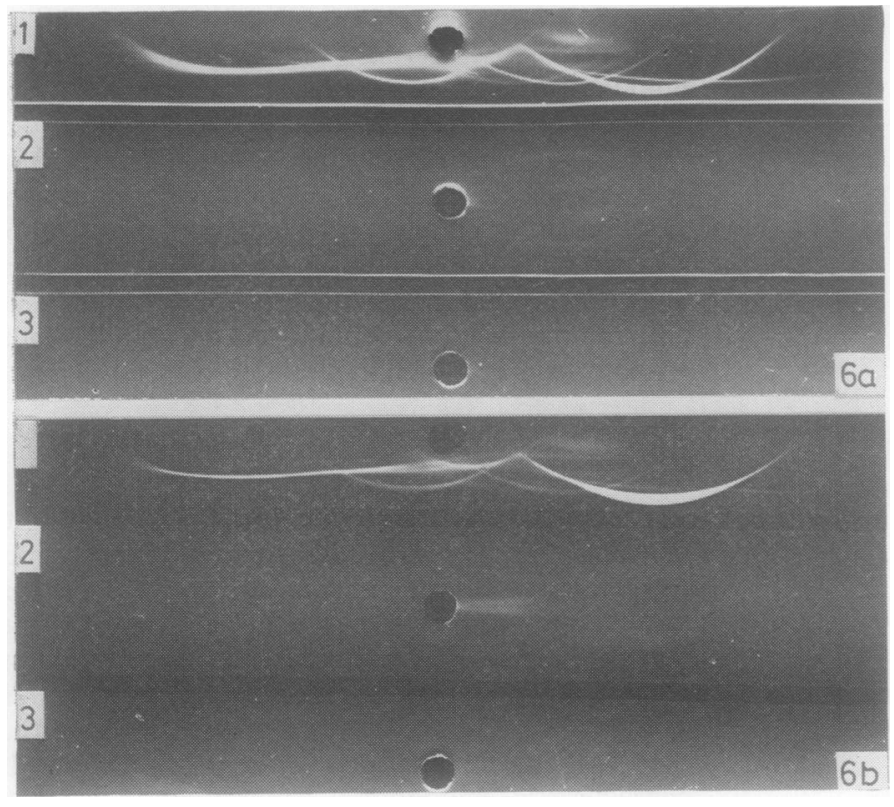

Fig. 6 (a) Immunoelectrophoresis of EST 1 against antiserum to human whole serum. 1, Control human serum. 2, Mouse serum with EST 1. 3, Control mouse serum. (b) Immunoelectrophoresis of EST 2 against antiserum to human whole serum. Numbers 1 to 3 are as for (a).

patients with endodermal sinus tumour (Tsuchida et al., 1975; Nørgaard-Pedersen et al., 1976).

Zondag and Klein (1968) found that LDH 1 or LDH 1 and 2 are the predominant isozymes in seminoma, dysgerminoma, and teratoma. LDH 1 was predominant in the sera and tumours of patients 1 and 2. Pesce et al. (1977) reported that human tumours implanted into nude mice released LDH isozymes that are unique to human tissue and that these isozymes could readily be identified and measured in mouse plasma. In our study, the two tumours produced large amounts of LDH 1 only. Therefore, LDH 1 should be useful as a marker in the diagnosis and management of cases of endodermal sinus tumour.

Fishman et al. (1976) proposed three phases in the development of alkaline phosphatase in human trophoblasts: placental-type alkaline phosphatase appeared in phase 2 (11 to 13 weeks' gestation), whereas liver and bone type alkaline phosphatase was produced in phase 1 (6 to 10 weeks' gestation). Alkaline phosphatase in EST 1 and 2 resembled liver and bone type alkaline phosphatase in that it was heat-labile and was less inhibited by L-phenylalanine. This finding is consistent with the fact that the tumours produced fetal liver-specific AFP.

Another liver-specific function of serum protein production was demonstrated in these two tumours: EST 1 and 2 produced alpha-1-antitrypsin and albumin, respectively. Gitlin and Perricelli (1970) reported synthesis of serum albumin, prealbumin, AFP, $a_{1}$-antitrypsin, and transferrin by the human yolk sac. Sakashita et al. (1976) demonstrated the synthesis of AFP, albumin, transferrin, and $a_{1}$-globulin in human embryonal carcinoma. Yoshimura et al. (1978) reported three cases of yolk sac tumours producing albumin, $\alpha_{1}$-antitrypsin, and transferrin; prealbumin, $a_{1}$-antitrypsin, transferrin, and haemopexin; and $\alpha_{1}$-antitrypsin, respectively. The serum proteins produced seem to vary with each endodermal sinus tumour, although the production of serum proteins is an original function of yolk sac endoderm.

These endodermal sinus tumour lines in nude mice will be useful in studies on markers for the diagnosis and postoperative management of cases of tumour of this type.

We thank Dr M. Miwa, Virology Division, National Cancer Center Research Institute, for assaying AFP and CEA.

\section{References}

Bessey, O. A., Lowry, O. H., and Brock, M. J. (1946). A method for the rapid determination of alkaline phosphatase with five cubic millimeters of serum. Journal of Biological Chemistry, 164, 321-329.

Cabaud, P. G., and Wróblewski, F. (1958). Colorimetric measurement of lactic dehydrogenase activity of body fluids. American Journal of Clinical Pathology, 30, 234-236.

Fishman, L., Miyayama, H., Driscoll, S. G., and Fishman, W. H. (1976). Developmental phase-specific 
alkaline phosphatase isoenzymes of human placenta and their occurrence in human cancer. Cancer Research, 36, 2268-2273.

Fishman, W. H., and Singer, R. M. (1976). Regulatory controls of oncotrophoblast proteins and developmental alkaline phosphatases in cancer cells. Cancer Research, 36, 4256-4261.

Gitlin, D., and Perricelli, A. (1970). Synthesis of serum albumin, prealbumin, $\alpha$-foetoprotein, $\alpha_{1}$-antitrypsin and transferrin by the human yolk sac. Nature, 228, 995-997.

Kameya, T., Watanabe, K., Kobayashi, T., and Mukojima, T. (1973). Enzyme- and immunohistochemical localization of human placental alkaline phosphatase. Acta Histochemica et Cytochemica, 6, 124-136.

Nørgaard-Pedersen, B., Hertz, H., Sell, A., and Tygstrup, I. (1976). Infantile endodermal sinus tumors (yolk sac tumors) and alpha-fetoprotein. In Onco-Developmental Gene Expression, edited by W. H. Fishman and S. Sell, pp. 379-385. Academic Press, New York and London.

Pesce, A. J., Bubel, H. C., DiPersio, L., and Michael, J. G. (1977). Human lactic dehydrogenase as a marker for human tumor cells grown in athymic mice. Cancer Research, 37, 1998-2003.

Sakashita, S., Hirai, H., Nishi, S., Nakamura, K., and Tsuji, I. (1976). $\alpha$-Fetoprotein synthesis in tissue culture of human testicular tumors and an examination of experimental yolk sac tumors in the rat. Cancer Research, 36, 4232-4237.

Shimosato, Y., Kameya, T., Nagai, K., Hirohashi, S., Koide, T., Hayashi, H., and Nomura, T. (1976).
Transplantation of human tumors in nude mice. Journal of National Cancer Institute, 56, 1251-1260.

Teilum, G. (1959). Endodermal sinus tumors of the ovary and testis: comparative morphogenesis of the so-called mesonephroma ovarii (Schiller) and extraembryonic (yolk sac-allantoic) structures of the rat's placenta. Cancer, 12, 1092-1105.

Teilum, G., Albrechtsen, R., and Nørgaard-Pedersen, B. (1974). Immunofluorescent localization of alphafetoprotein synthesis in endodermal sinus tumor (yolk sac tumor). Acta Pathologica et Microbiologica Scandinavica, 82A, 586-588.

Teilum, G., Albrechtsen, R., and Nørgaard-Pedersen, B. (1975). The histogenetic-embryologic basis for reappearance of alpha-fetoprotein in endodermal sinus tumors (yolk sac tumors) and teratomas. Acta Pathologica et Microbiologica Scandinavica, 83A, 80-86.

Tsuchida, Y., Endo, Y., Urano, Y., and Ishida, M. (1975). a-Fetoprotein in yolk sac tumor. Annals of New York Academy of Sciences, 259, 221-233.

Yoshimura, S., Tamaoki, N., Ueyama, Y., and Hata, J. (1978). Plasma protein production by human tumors xenotransplanted in nude mice. Cancer Research, 38, 3474-3478.

Zondag, H. A., and Klein, F. (1968). Clinical applications of lactate dehydrogenase isozymes: alterations in malignancy. Annals of the New York Academy of Sciences, 151, 578-586.

Requests for reprints to: Dr T. Takeuchi, Biochemistry Division, National Cancer Center Research Institute, Tsukiji 5-chome, Chuo-ku, Tokyo, Japan. 